\title{
Forest and biodiversity conservation in ancient Indian culture: A review based on old texts and archaeological evidences
}

\author{
Sayan Bhattacharya \\ Department of Environmental Studies, Rabindra Bharati University, Kolkata, India \\ E-mail address: sayan_evs@yahoo.co.in
}

\begin{abstract}
In the early periods of human history, environment strongly determined the lives and activities of the people. They were very much close to forest and natural resources as we find in historical documents. Ancient Indian texts like Arthasastra, Sathapatha Bhramanas, Vedas, Manusmrti, BrhatSamhita, Ramayana, Mahabharata, Rajtarangini reflected the concepts of forest ecology and conservation in a sustainable manner. In the Indus valley civilization, several characteristics of the city planning and social structure showed environmental awareness. The presence of leaves, wild animals like peacocks and one-horned deer, tigers, elephants, bulls in the seals and the mud pots can indicate the pattern of biodiversity in those areas. Reduction of forests in that area was due to use of huge amount of timber-wood for burning bricks. So rainfall reduced and soil erosion caused deposition of silt in the Indus River which had choked off Mohenjodaro from the sea, causing a rise in the water table that must have been a prime factor in the destruction of Mohenjodaro. The sacred groves (Tapovana) of India were rich in biodiversity and ecological wealth, which was also mentioned in many ancient Indian documents like Abhigyan Shakuntalam written by Kalidasa. They are small packets of forests dedicated to local deities. In the Bhagavad Gita, Krishna compares the world to a single banyan tree with unlimited branches in which all the species of animals, humans and demigods wander, which reflects the concept of community ecology. The trees like Banyan and Peepal were often referred in historical background (widely protected in Asia and Africa) are keystone resources. In modern age, there are many policies developing in many countries for forest and biodiversity conservation, but they are all directly or indirectly influenced by the traditional knowledge developed in the ancient India.
\end{abstract}

Keywords: biodiversity; ancient India; forest; sustainability; environment

\section{INTRODUCTION}

The relationship between culture and ecology was the integral part of ancient Indian societies. Interactions with diverse biological entities and concern for their conservation remained important components in the structure of ancient civilizations of India. From the 
ancient age, human developed the capacity to transform the face of the earth. During the course of evolution of the human race, civilization has transformed the environment in countless ways and on an unprecedented scale. Use of fire, domestication of animals and early agricultural practices are the major steps to modify the already existing conditions. In the early periods of human history, environment strongly determined the lives and activities of the people. They were very much close to nature and natural resources as we find in historical documents. The ancient people developed many effective measures to safeguard our ecosystems and environment which reflect sustainable development in true sense. In our study, we try to highlight some texts and archaeological evidences of ancient India which can eminently reflect the perspectives of environment, forest and biodiversity conservation of our forefathers.

\section{CONCEPT OF FOREST AND BIODIVERSITY IN ANCIENT INDIAN TEXTS}

\section{Kautilya's Arthasastra:}

Kautilya, also known as Chanakya, was the minister of Chandragupta Maurya (321-297 BC), India's first emperor. The book Arthasastra written by him is a treatise on government and economics of ancient India. The book informed that the people knew about the rainfall regimes, soil types and appropriate irrigation techniques in specific micro-ecological contexts. Arthasastra had a number of sutras in different chapters dealing with various aspects of statecraft and administration, which shows environmental awareness. ${ }^{1}$

In the book, importance was given on the protection and management of forests, gardens, orchards as these all were considered as sources of revenue, besides being of recreational spots. The Arthasastra divided the country between the Himalayas and the oceans into various kinds of regions - Forests (aranya), Village areas (gramya), Mountains (parvata), Wet or humid areas (audaka), Drylands (bhauma), Plains (sama) and Uneven lands (visawa). The average annual rainfall in some of the famous places like Asmaka and Avanti was 13.5 and 23 dronas (1 drona $=1.5$ to 2 inches) respectively. Asmaka (upper Godavari plains), Avanti (Malwa) and Aparanta (Konkan) together formed a continuous territory. ${ }^{2}$

Arthasastra demonstrates Kautilya's perception and concern about the living creatures domestic and wild animals, plants and vegetations. Penalties and punishments were specified for injuring living creatures. Special positions were occupied by directors of forests, supervisor of animal slaughter, superintendents of cattle, horses, elephants, and pastures. These officials used to protect wildlife, ensured proper rations for pet animals, regulated grazing, prevented poaching of wild animals, ensured proper care of domestic animals etc. Individuals were supposed to follow norms about their dealing with the domestic animals. ${ }^{3}$ Non-agricultural lands were sometimes used for animal parks where animals were given full protection. In these sanctuaries, capture or killing of animals were prohibited. List of protected animals, fish, birds were found which executes the scientific knowledge of biodiversity. Village head-man was made responsible for preventing cruelty to animals in village communities. Details of care, training, and treatment of horses, elephants and cows had been indicated. ${ }^{3}$

The king is supposed to protect forests, elephant forests, irrigation works and mines that were made in ancient times and also should start new ones. Forests were considered as a valuable resource, forest products should be used in a sustainable manner and factories for goods made from forest products should be started as Kautilya mentioned in Arthasastra. For 
cutting any part of a tree, fines of variable amounts were imposed on the offender depending on the types of injury. Emphasis was given particularly on those which bear fruits, flowers or provide shades. Among material forests, one which was large, full of resource, accessible and watered by a river was given more importance, because it could be a shelter in time of trouble. ${ }^{4}$

The environmental issues described in Arthasastra are very much relevant in modern society. In 1972, the conference on human environment in Stockholm mentioned about some principles which were very much similar to the edicts of Arthasastra. Even in India, some of the environmental laws like Water (prevention and control of pollution) Act 1974, The Forest Conservation Act 1980 and The Wildlife (Protection) Act 1972 show amazing similarity with forms and contents of Arthasastra.

\section{Manusmruti:}

From Manusmruti, written in the post-Vedic age, we can realize that religion plays diversified role in saving the integrity of the natural environment. Manusmruti is the world's first ethical compendium on human jurisprudence, presented by Maharshi Manu, originated sometimes immediate to the post Vedic age. ${ }^{5}$

In the dicta for prevention of pollution in Manusmruti, we can get the reflection of ecological awareness:

1. Biodiversity means all living forms broadly ascribed as Chara (movable living world) and Achara (immovable: plant kingdom).

2. Pollution refers to spoilage of the five gross elements by unethical activity.

3. Contamination refers to any action against wholesomeness (Ssoucha).

4. Storage organs of plants like tuberous roots and underground stems, leafy vegetables, beautiful flowers, tasteful fruits, timber yielding trees, crops etc. remained objects of allurement in that period. For saving the plants and their parts from injury, Manusmruti describes various punishments for the offenders. ${ }^{6}$

5. Importance was given for conserving and domesticating animals, biodiversity protection, and vegetarian food habit. According to Manu, agriculture caused injury to animals, specially the insects and germs in the soil. ${ }^{7}$

6. For biodiversity protection, he mentioned that fishes of all types should not be killed for food purpose; one hoofed animals, village pigs, solitary moving animals and unknown beasts should be protected; carnivorous birds, birds of village habitat, web footed birds, diving birds feeding on fishes, birds with striking beaks should not be killed for the purpose of eating. He stated that killing of Khara (ass), asva (horse), ustra (camel), mrga (deer), ibha (elephant), aja (goat), ahi (snake), ahisa (buffalo) is a sin. ${ }^{7}$

\section{Caraka-Samhita and Susruta-Samhita:}

Caraka-Samhita and Susruta-Samhita are considered as the significant ancient Indian documents in medical science. These books have several chapters which describe different diseases, their treatment procedures and also can be considered as excellent texts for revealing the utility of medicinal plant resources. Apart from documenting the medical perspectives, they dealt with the ecological and environmental perspectives as well. Caraka and Susrata classified lands according to the nature of the soil, climate and vegetation into three categories: 
a. jangala, or the region of open spaces where a steady dry wind blowed. The common plants of the region were khadira (Acacia catechu), asana (Terminalia tomentosa) and badari (Zizyphus jujuba).

b. апира, or the marshy tract bordered by seas, where cold wind and networks of rivers prevailed. The common plants were vanjula (cane or reed), hintala (kind of palm) and narikela (coconut), varieties of lotuses and water lilies, variparni (Pistia sp.), musika-parni (Salvinia sp.), jalanili (algae) and saivala (moss).

c. sadharana, or the intermediate regions which had some of the features common to the other two regions. The common plants were mandara or parijataka (coral tree) and santana (kalpa tree). ${ }^{8}$

Susruta classified animals on the basis of their food habits and habitats. He also classified edible fishes into freshwater and saltwater varieties. The behaviors, mode of life and ecological distribution of many animal species can be gathered from his writings. ${ }^{9}$

\section{The Vedas:}

Some elements of the religious and cultural practices from the Indus period and other indigenous (especially aboriginal) communities continued into the Vedic age, which was introduced by Aryans or 'Noble People', a tribe of pastoral nomads from somewhere in Central Asia who settled on the plains of the Ganges in northern part of the subcontinent around second millennium BCE. Aryans influenced the Indian culture through their activities many of which had environmental significance.

Vedas are the sacred Sanskrit texts of Hinduism. According to some scholars, the great sage Ved Vyasa codified and put the Vedas into writing at the beginning of Kali Yuga (3102 BC). These are the Shruti Vedas, which include: Rig Veda (Wisdom of the Verses), Sama Veda (Wisdom of the Chants), Yajur Veda (Wisdom of the Sacrificial Formulas), and Atharva Veda (Wisdom of the Atharvan Priests). Initially, the Shruti Vedas consisted of four collections of mantras (Samhitas), each associated with a particular priest or aspect of ritual. Over centuries, three kinds of additional literature were attached to each of the Samhitas: the Brahmanas (discussions of the ritual), Aranyakas (books studied in the forest), and Upanishads or the philosophical writings. ${ }^{10}$ Of these, Aranyakas or the "forest" works (aranya in Sanskrit means 'forest' and aranyaka means 'in the forest') and the Upanishad 'Brhadaranyaka' (translated as "Great Forest Text") are particularly important from the perspective of forestry traditions. ${ }^{11,12,13}$ Although aranyakas provide the theological foundations of early Hinduism, which is outside the realm of forestry, some of these descriptions are relevant to indigenous ecological knowledge, on which there is considerable interest now. ${ }^{14,15}$

The Aryans practiced irrigation based seasonal agriculture and used organic fertilizers in agricultural fields regularly. Each village had separate grazing land for the cattle. Pastoralists subsisted on the animal products (milk, meat, skins, hair, wool), but grains and other plant foods were usually acquired from other groups. Pastoralists may be either sedentary or mobile. People may pasture their animals in the vicinity of their habitation and fields. Once the food sources were consumed, a herd may need to move away to a distance from which the shepherds could bring the animals back. The distinctive feature of agropastoral systems was that they were very much concerned about animals as resource, and their produce, much more than they do food grains, in spite of people eating more of the latter. The crop most frequently mentioned was yava or barley, a cereal that withstands drought, can adopt to high and to low altitudes, and has a short growing season. The word 
'odama' may possibly indicate a variety of rice, a rare one. Small rectangular mud-brick houses were subdivided into rooms and cubicles that could have been used for storage of grains and other necessities. ${ }^{16}$

The Vedas specified four types of living beings, namely andaja (born of eggs), jivaja (born of womb), svedaja (born of moisture) and udbhija ( born of earth ) and declared that these are impelled by prajnaman ( consciousness ). The Vedas described the diversified range of flora and fauna and urge the human beings to protect, preserve, nurture and nourish the environment and natural world. For the benefit of the humans and other living organisms they prescribed a pleasant environment consisting of sweet breeze, sweet flowing rivers, beneficial herbs, sweet day and night, sweetness of earth particles, sweet fruit bearing trees, beneficial sun and healthy cows. Importance was given on the habitats which should be protected. For the protection and development of forests, concept of afforestation was developed. ${ }^{17}$ Plants were compared with mother, friends and deities. The voice of the trees was compared with the sounds of drums, lutes and flutes.

Water was considered as the symbol of purity which should be free from pollution. With a social objective, they emphasized that water is a common resource to be used by all. $R g$ Veda contains many notes on irrigated agriculture, river courses, dykes, water reservoirs, wells and water lifting structures. ${ }^{18}$ Water was compared with living beings, creator, edible crops, truth, desires which in totality signifies the ecological and environmental dimensions. Animals were divided in terms of those of the air (vayavya), those of the jungle (aranya) and those of the village (gramya). Prayers were offered for the welfare of animals. Plants were classified into trees, shrubs with spreading branches, herbs, spreading or deliquescent plants, bushy plants, climbers, creepers, creepers spreading on the ground. The Vedas hailed the trees, the roots, the panicles, the corona, the branches, the leaves, the flowers and the fruits. Herbs were considered to have remedial powers.

$R g$ Veda mentioned that plants had preceded animals, particularly man, in the process of evolution. In Upanishad, the idea of evolution was expressed as 'From that very Atman ether came to be; from ether air, from air fire, from fire water, from water the earth, from the earth herbs, from herbs food and from food the person came into existence'. ${ }^{19}$

The oral tradition and the Veda would have to be among the earliest record of ruminations on nature and environment in India. In the Vedic literatures mother Earth was personified as the goddess Bhumi, or Prithivi. Her beauty and profusion were vividly portrayed in the Atharva Veda: "O mother, with your oceans, rivers and other bodies of water, you give us land to grow grains, on which our survival depends. Please give us as much milk, fruits, water and cereals as we need to eat and drink." The Chandogya, one of the principal Upanishads pointed out:

"The rivers -------- all discharge their waters into the sea. They lead from sea to sea, the clouds raise them to the sky as vapour and release them in the form of rain....." This is probably the oldest reference of hydrological cycle. ${ }^{1}$

In Ishopanishad, the concepts of sustainable development and conservation were established: "All in this manifested world consisting of moving and non-moving are covered by the lord. Use its resources with restraint. Do not grab the property of others- distant and yet to come.". 1

The later Vedas, especially the Ayurveda section, demonstrate profound knowledge of biodiversity. The inter-relationship between living species and the environment was established. It described the need to maintain natural dynamism, the right ways of handling plants and trees, native flora and fauna and the price one should pay for going against the ecological principles. Medicinal plants such as palash, arjun, yava, laksha, haridra, haritaki 
etc. were widely used for treatment. Among post Vedic ancient texts, a classic work was Surapala's Vrikshayurveda, which executed knowledge of soil, seed, manure, irrigation and care for health and proper growth of plants. Vrikshayurveda means the science of plant life, which is known to have existed in ancient India as a special branch of knowledge. This traditional document mainly deals with the practical aspects of plant science. The chapter "Bijotpatti Kanda" describes the forest ecosystems. Forests were referred by different names like 'atavi', 'bipina', 'gahana', 'kanana', 'bana', 'aranyani' etc. The books described forests where trees, shrubs, creepers and grasses grow naturally. Classification and characterization of woodlands were done according to their location and natural surroundings. ${ }^{20}$

Banwari, the day-editor of Jansata, a Hindi daily newspaper published in Delhi, has made a detailed study of the forest culture of India. He wrote: "Hindu tradition describes three basic categories of forests. One is shrivan, the forest which provided prosperity. Tapovan where one could contemplate as the sages did and seek after truth. The third is mahavana, the great natural forest where all species of life find shelter.". 21

Once some of the original forests were cleared, however, Vedic culture required that another kind of forest be established in its place. Each village preserved sections of forests (shrivan) for their own specific needs. These forests were different from the mahavanas, the wild forest or jungle, because they were open for exploitation and harvesting according to strict ecological practices. These were the forests of wealth and the basis of community s prosperity. In Vedic age, each village was responsible through its pancayat, or committee of five elders, for maintaining the forests in its own locality. No village was complete without its corresponding woodlands in and around its houses.

"The Hindu idea is that this whole world is a forest. To keep this world as it is we have to keep the world forest intact". ${ }^{22}$ This gave rise to the concept of cultural landscapes such as sacred forests and groves, sacred corridors, and a variety of ethno-forestry practices that reflect the ecosystem-like concepts in traditional societies. ${ }^{23}$ In the post-Vedic period, this tradition continued; in addition to considering a landscape as such valuable and sacred, individual species and micro-units were also treated as sacred. ${ }^{11}$ Examples include the temple forests, monastery forests, sanctified and consecrated trees, the sacred forests, sacred groves, sacred trees etc.

\section{The Ramayana, Mahabharata, Bhagabat Gita and Abhigyan Shakuntalam:}

According to the Mahabharata, Hastinapur, the capital of Kurus was situated in a forested area. It also mentioned that the kingdoms of Kurus and Panchalas - covering roughly the upper Gangetic plains - were located in forested area. Devipurana (chapter 14) mentioned nine sacred forests of which Kuru jungle, Nimisha and Utpalaranya covered the upper Ganga plains. Pollen records from Hastinapur excavations show the presence of Pinus, Dalbergia, Holorabera etc. ${ }^{24,25}$

When the Pandavas was given half the kingdom, they had to build their capital, Indraprastha. This required the clearing of the forests and in order to do this effectively the god Agni burnt the forest. Krishna and Arjuna went to Khandava forest which was situated on the bank of Yamuna, where Delhi stands today. Agni's appearance as a Brahman begging alms was significant, because Brahmans played an important role in the process of colonization.

In Ramayana, the prince of Ayodhya, was about to set out on his long exile in the forests south of the Gangetic plains, his mother Kaushalya, expressed fear about his safety: "May the huge elephants not harm you my dear son, nor the lions, tigers, bears, boars or ferocious horned buffalo. "The forested lands were a source of pleasure for Sita. Reference of 
lotus ponds, geese, ducks, honey-scented groves, herds of deer were found. When building their home in the forest, they first sacrificed one of the present day endangered species, the blackbuck. Lakshmana made sure the animal was killed but left with its limbs intact to be cooked, broiled and only then offered to god. The antelope, the krisnasara, had long represented the culture of the open spaces, of cereal- bearing dry land. Aryavartya, the land of the Aryans, was often co-terminus with the land of the black antelope. These were areas to the north of the Vindhya mountain chain. ${ }^{26}$

Ramayana described that Arjuna (Terminalia arujuna), Jupa Puspa or Karnikar (Hibiscus mutabilis/Hibiscus rosasinensis) etc. were favourite trees of Sita. The Asoka Garden of Ravana had Sala (Shorea robusta), Asoka (Saraca indica), Champa (Michelia champaca) etc. In that period, the Chandan or Sandal Wood trees (Santalum album) were very popular. ${ }^{27}$

The gradual clearing of forests over the centuries has changed the ecology of certain regions. The pace of change was not uniform. It was slower in earlier times and more limited in its geographical area, but as the demand for land increased, the clearing of the forests become faster and the area so cleared, larger.

In the Abhigyan Shakuntalam, Dusyanta went on a hunt, accompanied by a large number of warriors, and they indiscriminately killed the animals (herds of deer, tigers and elephants). The people of the settlement were demonstrating their power over nature. Also in the play, the closeness of man to the forests through ashrama life was demonstrated. The forest was executed as a place of peace and gentleness, where even the plants and the deer were very close to Shakuntala. Kalidasa romanticized the forest life to make it more familiar. ${ }^{28}$

Sacred groves are small packets of forests dedicated to local deities. They are a common phenomenon in many parts of the country particularly in the north- eastern regions and the Western Ghats. ${ }^{26}$ These dark evergreen forest patches are believed to be sacred to the village god or goddess, and have been preserved from time immemorial. Many of them contain climax level vegetation and harbour rare and little known species of plants. Sacred groves not only protect the ecology of that region but also provide dry fuel wood, dry leaves and many kinds of non-wood produce for the village communities. Some previous studies reported the existence of over 10,000 sacred groves in India. These forest patches harbor huge trees and giant climbers and serve as repositories of rare, endemic and endangered organisms. The ancient cities of Vaisali, Kushinaraand, Champa, all maintained sacred groves. The groves may even have been specially planted as they are often described as being of specific kinds of trees, such as Banyan or the Sala. Vrajbhumi, the region around Vrindavana, always had a very good environmental balance, following the traditional pattern of Hindu India. Many ancient Indian texts highlighted the concept of sacred groves through the ages.

In the Bhagavad Gita, Krishna compared the world to a single banyan tree with unlimited branches in which all the species of animals, humans and demigods wander, which reflects the concept of community ecology. The trees like Banyan and Peepal were often referred in historical background (widely protected in Asia and Africa) are keystone resources. The worship of trees as a part of fertility cult remained a constant feature of the religion of pastoralists, peasants and those of lesser status among urbanites. ${ }^{29}$

Srivastava Goswami, a vaishnava scholar considered the life of Krishna 'the greatest chapter in environmental history'. ${ }^{21} \mathrm{He}$ says that there were only two recorded occasions when Krishna performed formal religious worship, and on both these occasions he worshipped nature. Krishna said that all creatures are born, die, and get pleasure and pain by 
the force of karma; so there is no necessity to worship Indra (the lord of water) as everyone could control its own destiny. He also said "your environment is your concern, it is your duty." Krishna taught that it was better to worship the hills, forests and cows than to perform a ritual for the demigods. Krishna defeated the serpent kalya and purified the Yamuna River. He swallowed the forest fire to protect the forest. He looked after the cows. He spoke to the birds in their own language. He was always protecting nature.

Krishna praised the trees of Brindavan: "they have dedicated their lives to the welfare of others. Individually they are tolerating all kinds of natural disturbances............ They supply various kinds of facilities to human society, such as leaves, flowers, fruits, shade, roots, bark, flavour extracts and fuels." (Srimad Bhagavatam 10.22.32-35). ${ }^{29}$

Vrindavana was famous for its groves of sacred kadamba, papal, tamal, amalaki and $v a t a$, but now is almost bare. The environment was also very pleasant, as mentioned in Srimad Bhagavatam: "Krishna brought forward the cows and played on his flute through the forest of Vrindavana, which was full of flowers, vegetables and pasturing grass.......... full of bees, flowers and fruits. There were chirping birds and clear water lakes......... Sweet flavoured breezes blew always, refreshing the mind and body."

There are many stories in the Vedic literature which showed the interactions between worldly persons and sages in their forest ashramas. From this profoundly natural setting emerged the Vedic teachings of the Upanishads such as the Brihad-Aranyaka, which means 'the teaching which began in the forests'. The beauty of natural creation was called in Sanskrit vanavaibhava. It could be argued that the romanticization of the forest began when it was thought that culture was suppressing nature. In the period of Banaprastha and Sanyas, for a man the forest was an avenue to the discarding of the mantle of civilization and the discovery of the self.

Some categories of literatures are very aware of ecological differences and their links to culture. Thus the Tinnai concept of Tamil Sangam texts, composed around the start of the Christian era, is a fascinating example of detailed and early perception of the significance of the eco-zones. The landscape had been classified by five types of eco-zones which were interrelated with the cultural and social structure of society. The zones were listed as the littoral, the wetlands, the pastoral tracts, the dry zones and the hilly backwoods. Fishing and the making of salt was important in the coastal areas, the cultivation of rice in the wetlands, the breeding of livestock and practice of shifting cultivation in the pastoral tracts, which were subject to cattle-lifting from those who lived in the dry-zones, and hunting and gathering was associated with back wood life. Wetlands were extremely limited as compared to the noncultivable tracts, but over a period of time this changed. There were some interactions through the exchange of paddy and salt for other products, generally at the exchange centers. There have been some historical studies attempting to trace the process by which these micro eco-zones gradually evolved into macro-zones.

\section{ENVIRONMENT, FOREST AND BIODIVERSITY ISSUES IN INDUS VALLEY CIVILIZATION}

The Indus Valley Civilization was a Bronze Age civilization (3300-1300 BCE; mature period 2600-1900 BCE) extending from what today is northeast Afghanistan to Pakistan and northwest India. Along with Ancient Egypt and Mesopotamia, it was one of three early civilizations of the Old World, and of the three the most widespread. It flourished in the basins of the Indus River, one of the major rivers of Asia, and the Ghaggar-Hakra River, 
which once coursed through northwest India and eastern Pakistan. Several characteristics of the city planning and social structure showed environmental awareness but it was the environmental change which was probably the main reason behind the fall of this civilization. ${ }^{30}$

In terms of productivity it was not a very productive region. Some rainfall occurred due to the monsoon and the depression belt generated on the Mediterranean Sea and a little in the winter. But the rainfall in winter was not at all sufficient for cultivation. The main crops in the winter were barley, wheat, peas and pulses. In summer, cotton was one of the important productions. They also practiced intensive agriculture. Crops were stored in storerooms covered by wooden doors. ${ }^{30}$

In August, there was flood every year in the Indus valley, but in winter the water level dropped. They used to store water for cultivation in winter. The area of cultivation was changed every year depending on the amount of rainfall and the direction of river flow. The people often used the ground water because of insufficient rainfall. They used the bulls in irrigation to overcome the water stress. In winter water often stored in the lowlands. Many anthropologists think there was an epidemic of malaria due to the increase in mosquito population in stored and confined water. ${ }^{1}$

In many coins and seals in Harappa there were a variety of animals including elephants, rhinoceroses and tigers. But at present, there is no forest area in Harappa and Mahenjodaro, which can indicate the changes in climatic conditions. In 1333, an Arabian traveler saw rhinoceros in the Indus valley and later British rulers went to Indus valley for hunting tigers. The presence of leaves, wild animals like peacocks and one-horned deer, tigers, elephants, bulls in the seals and the mud pots reflect their views towards natural resources. ${ }^{30}$ Ficus religiosa, which has perhaps the longest continuity of a sacred tree in India, occurs on the seals from the Indus civilization, it is associated with Buddhism and is depicted in sculpture from Buddhist places of worship and it continues to be venerated in association with religious shrines of Hindus and Muslims.

An icon, which had both the characteristics of human and other animals and the image of tree god in the seals, reflects their closeness with nature. In their Shamanistic religions wild animals played a major part. In the seal of 'Pashupati', a man was encircled with animals proved that they often went to the forest to spend a part of their life. ${ }^{30}$

About 50 years ago, Sir Aurel Stein (1931) and Sir John Marshall (1931) on the basis of their evaluation of the multiple archeological evidence from Baluchistan and Sind, proposed that climate in these regions during the Indus civilization period was wet than it is as present. This theory was accepted and supported by archaeologists like Stuart Piggot (1950) and Mommer Wheeler. Wheeler revealed that ample and equable rainfall in the Indus valley had made the plain alluvial and made it fit for human habitation. Probably large amount of local fuel were available in the Indus valley. The floating timbers from the Himalayan forests were used to prepare burnt brick which was a special characteristic of the Indus cities- Harappa, Mahenjodaro, Chanhodaro and Sutkajender. These cities were easily accessible by water whilst other cities were less accessible and were seemingly content with stone and brick. The Indus valley people were mainly dependent on irrigation and overseas trade, which were possible because of the rain fed soil and the easy access to sea. ${ }^{26}$

Reduction of forests in that area was due to use of huge amount of timber-wood for burning bricks. So rainfall reduced and soil erosion caused deposition of silt in the Indus River which had choked off Mohenjodaro from the sea, causing a rise in the water table that must have been a prime factor in the destruction of Mohenjodaro. Inadequate maintenance of dams and irrigation channels hastened the downfall of the civilization. Falling off in 
agricultural standards, internal breakup of the administration, lack of planning, untidy housing and the use of old bricks in the reclining days were some of the glaring reasons to show the growing apathy of the people towards maintenance and order. ${ }^{31}$

The river Indus had also changed its direction leaving large tracts of land not only barren, but infected with germs due to reduction in precipitation and moisture. A large number of people were the victims of diseases which were spread all over the cities. People began to move southwards to Lothal and Saurashtra region in search for food and shelter. Thus the socio-cultural pattern of the Harappan civilization was probably getting out of hand with the spread of the culture to the south and east of the Indus valley. Seven layers of the civilization have been found after excavation in 1924, which indicates that the civilization was seven times built and seven times ruined due to some ecological problems. ${ }^{26}$

Causes of erosion was also because of intensive agriculture, depletion of soil nutrients by inadequate crop rotation, disturbance of the natural pattern of drainage by the slow rise of river bed and banks as a result of silting and overgrazing because of the insufficient food of the cattle. ${ }^{26}$

The palynological evidence came from three salt lakes namely Sambar, Didwana and Lunkaransar and one fresh-water lake, Pushkar in Rajasthan. The climate sequence based on the pollen records indicates primitive cereal agriculture (7500 BCE-3000 BCE) and scrub burning proved by extraordinary rise in carbonized vegetable remains in the lake sediments at all sites and the appearance of the Cerealia type of pollen. ${ }^{26}$

The shift of the courses of the Yamuna and Sutlej to the east and west respectively, would have considerably reduced the availability of both surface and sub-surface water in the Ghaggar valley. This could, in due course, had adversely affected both natural vegetation and agriculture, and forced the people to shift the areas like north Punjab (Sutlej channel) and the upper Yamuna-Ganga doab where the rivers provided the ecological conditions the Harappans had long been accustomed to exploit.

\section{CONCLUSIONS}

With the advancement of civilization and development, environment has become affected to a considerable extent. Environmental degradation has raised the uncomfortable questions about the concept of development itself. With environmental degradations, a large section of people has become marginalized and their live and livelihood has faced grave concerns. Development as expected has increased consumerism in a small section of the society, but it has degraded and depleted natural resources simultaneously. It is a need of the hour to secure the right to save food, water, air and all other natural ingredients in particular and environment in general. To get rid of the emerging environmental and ecological problems of modern civilized societies, there is an increasing trend of consciousness growing among us. There are many policies developing in many countries for environmental protection, but they are all directly or indirectly dependent on the traditional knowledge developed in the ancient age which teaches us the concept of the value of a simple life. We can follow the simple policies of our forefathers who probably had much better understanding of the environment than we currently have. Detailed studies are urgently needed to extract, analyze and implement the ancient Indian environmental and ecological conservation policies in modern societies, so that in near future we can get a more stable, clean, rich and healthy environment. 


\section{References}

[1] Bhattacharya S., Chaudhuri P., Mukhopadhyay A., Journal of Ancient Indian History 24 (2008) 97-106.

[2] Anon, Irrigation in India through the ages. Central Board on Irrigation and Power, New Delhi, India (1965).

[3] Kangle R. P., The Kautilya Arthasastra. Second edition. University of Mumbai, part I and II (1986).

[4] Rangarajan L. N., Kautilya- The Arthasastra. Penguin Classics, India (1992).

[5] Buhlar G., The laws and Manu. In: Max Mullar, F. (Ed.), The sacred book of the east. Oxford at the Clarindon Press, London (1886).

[6] Padhy S., Dash S., Mohapatra R., Journal of Human Ecology 19(1) (2006) 1-12.

[7] Sensharma P., Indian journal of history of science 33(4) (1998) 267-272.

[8] Majumdar G. P., Botany in Ancient and Medieval India. In: Ray, P., Sen, S.N. (Eds.), The Cultural Heritage of India, Vol.VI. The Ramakrishna Mission Institute of Culture, Calcutta, India (1978).

[9] Ray P., Zoology in Ancient and Medieval India. In: Ray, P. Sen, S.N. (Eds.) The Cultural Heritage of India, Vol.VI. The Ramakrishna Mission Institute of Culture, Calcutta, India (1978).

[10] Bloomfield M., The Religion of the Veda: The Ancient Religion of India, from RigVeda to Upanishads. Knickerbocker Press, New York, USA (1908).

[11] Pandey D. N., Ethnoforestry: Local Knowledge for Sustainable Forestry and Livelihood Security. Himanshu/AFN, New Delhi, India (1998).

[12] Keith A. B., The Aitareya Aranyaka. (Edited from the Manuscripts with Introduction, Translation, Notes, Indexes, and an Appendix containing the portion hitherto unpublished of the Sankhayana Aranyaka.) Eastern Book Linkers, Delhi, India (2005).

[13] Witzel M., Katha Aranyaka. (Critical Edition with a Translation into German and an Introduction.). Harvard Oriental Series, Harvard Department of Sanskrit and Indian Studies. Harvard University Press, USA (2005).

[14] Gadgil M., Hemam N. S., Reddy B. M., People, refugia and resilience. In: Berkes, F., Folke, C. (Eds.), Linking Social and Ecological Systems: Management Practices and Social Mechanisms for Building Resilience Cambridge University Press, Cambridge, UK (1998).

[15] Folke C., Ecology and Society 9(3) (2004) 7.

[16] Thapar R., Kenoyer J. M., Deshpande M. M., Ratnagar S., India: Historical Beginnings and the Concept of the Aryan. National Book Trust, New Delhi, India (2007).

[17] Vannucci M., Ecological readings in the Veda. D.K. Print World, New Delhi, India (1994).

[18] Agarwal A., Narain S., Dying wisdom. Rise, fall and potential of India's traditional water harvesting systems. (State of India's Environment - A Citizens' report, No. 4), Centre for Science \& Environment (CSE). New Delhi, India (1997). 
[19] Majumdar G. P., Botany in Ancient and Medieval India. In: Ray, P., Sen, S.N. (Eds.), The Cultural Heritage of India, Vol.VI. The Ramakrishna Mission Institute of Culture, Calcutta, India (1978).

[20] Sircar N. N., Sarkar N., Vrksayurveda of Parasara: A treatise of plant science. Sri Satguru Publication, A devision of Indian Book Centre, New Delhi, India (1996).

[21] Prime R., Hinduism and Ecology: Seeds of Truth. Motilal Banarsidass Publishers Pvt. Limited., Delhi, India (1994).

[22] Pandey D. N., Conservation Biology 17(2) (2003) 633-635.

[23] Berkes F., Kislalioglu M., Folke C., Gadgil M., Ecosystems 1 (1998) 409-415.

[24] Chaudhuri, K.A., Ancient agriculture and forestry in northern India. Asia Publishing House, New Delhi (1977).

[25] Lal B. B., Excavations at Hastinapura and other exploration in the Upper Ganga and Sutlej basins. Ancient India, 10-11, 5-155 (1954-55).

[26] Rangarajan M., Environmental issues in India: A Reader. Pearson Education, New Delhi, India (2007).

[27] Sattar A., Ramayana. Penguin Books, India (2012).

[28] Kaushik A., Kalidas’ Abhigyan Shakuntalam. Motilal Banarsidass Publishers, India (2010).

[29] Swami A. C., Srimad Bhagavatam. Bhaktivedanta Book Trust, India (1976).

[30] Ratnagar, S., Understanding Harappa- civilization in the greater Indus valley. National Book Agency, New Delhi, India (2003).

[31] Dasgupta T., Chattopadhyay R. N., Journal of Human Ecology 16(3) (2004) 197-201. 